\title{
EXPERIMENTAL INVESTIGATION OF THE CAVITATION EROSION OF A FLAT ALUMINUM PART USING A SONOTRODE TEST DEVICE
}

\author{
EKSPERIMENTALNA RAZISKAVA KAVITACIJSKE EROZIJE \\ PLOŠČATIH DELOV IZ ALUMINIJA Z UPORABO SONOTRODA
}

\author{
Harun Dursun', Gökhan Sevilgen²*, Mehmet İhsan Karamangil ${ }^{2}$ \\ ${ }^{1}$ Robert Bosch GmbH, Diesel Systems, TR-16140 Nilüfer, Bursa, Turkey \\ ${ }^{2}$ Department of Automotive Engineering, Faculty of Engineering, Bursa Uludağ University, TR-16059 Bursa, Turkey
}

Prejem rokopisa - received: 2018-11-26; sprejem za objavo - accepted for publication: 2019-03-27

doi: $10.17222 / \mathrm{mit} .2018 .255$

In this paper we aimed to determine the gap distance between a horn and an aluminum part that ensures the highest cavitation erosion rate in a homogeneous delaminated area and provides the minimum energy consumption. For this purpose, a sonotrode device, which is capable of generating cavitation bubbles in the laboratory and enabling the evaluation of the cavitation resistance of parts with different parameters, was used in experiments. An optical microscope was used to visualize the surface delamination area where the cavitation erosion occurs, and a high-precision scale was used for measuring the total mass loss due to the cavitation erosion for each test. A high-speed camera was used to visualize the shape and behavior of the flow characteristics below the sonotrode. From the experimental results it is clear that the delamination area decreased with the increasing gap distance due to the impact region of bubble structures on the part surface. The gap distance clearly had a great effect on the cavitation erosion rate that must be determined while considering the energy consumption, test time and maximum homogeneous delaminated area in a specific cavitation test. The optimum distance was obtained as $3.5 \mathrm{~mm}$, by considering the maximum cavitation erosion rate and using minimum power.

Keywords: ultrasonic cavitation, sonotrode, cavitation erosion, flat horn

Avtorji opisujejo določevanje velikosti reže med oddajnikom ultrazvočnih valov (sonotrodom) in delom iz aluminija, ki omogoča najvišjo hitrost kavitacijske erozije $\mathrm{v}$ homogenem delaminiranem preseku in istočasno zagotavlja najmanjšo porabo energije. V ta namen so za preizkuse uporabili napravo (sonotrod), ki je sposobna generirati kavitacijske mehurčke v laboratorijskih razmerah in omogoča ovrednotenje kavitacijske upornosti Al izdelkov pri različnih procesnih parametrih. Za vizualizacijo delaminirane površine (odluščenih plasti) na mestih, kjer je nastopil proces kavitacije, so uporabili optični mikroskop. Pri vsakem preizkusu so uporabili natančno merilno metodo za merjenje izgube celotne mase zaradi kavitacijske erozije. Uporabili so visokohitrostno kamero za vizualizacijo oblike in karakteristik toka medija pod sonotrodom. Eksperimentalni rezultati so jasno pokazali, da se delaminacijski presek s povečevanjem reže zmanjšuje zaradi strukture mehurčkov v udarnem področju na površini Al dela. Širina reže ima nedvoumno velik vpliv na hitrost kavitacijske erozije. Avtorji ugotavljajo, da mora biti le-ta določena glede na porabo energije, čas preizkusa in maksimalnega homogenega preseka delaminacije za točno določen (specifičen) preizkus kavitacije. Določili so optimalno velikost reže. Ta je znašala 3,5 mm, upoštevaje maksimalno hitrost kavitacijske erozije pri uporabi najmanjše moči.

Ključne besede: ultrazvočna kavitacija, sonotrod, kavitacijska erozija, ploščato trobilo oz. rog (sonda za oddajanje ultrazvočnih valov)

\section{INTRODUCTION}

Cavitation is a phase-change process defined by the formation of the vapor of a liquid as a result of a pressure drop at constant ambient temperature. ${ }^{1}$ Cavitation effects are observed where the pressure and velocity in a fluid changes dramatically, including in many engineering components, such as pumps, turbines, ships' propellers and injectors. ${ }^{2}$ On the other hand, the stages of bubble formation in acoustic cavitation were depicted in Figure 1. ${ }^{3}$ The collapsing of these bubbles near a solid wall produces the material erosion due to cavitation. One of the test methods that can be used for the formation of cavitation bubbles and observing their effects on the metal parts is the acoustic cavitation test

*Corresponding author's e-mail:

gsevilgen@uludag.edu.tr method according to the ASTM G32-10 standard. ${ }^{4}$ The distance between the sample and the sonotrode in the indirect method described in this standard influences the intensity of the erosion and the test duration. ${ }^{5}$ On the other hand, the test results of the two types of samples show that the different total test time was obtained for these samples, although they had a similar cavitation erosion resistance. ${ }^{6}$ The total test time has to be optimized for different materials considering the cavitation erosion rate in the indirect method..$^{7}$ Cavitation erosion had four stages, which were the incubation, acceleration, maximum rate and deceleration. ${ }^{8}$ Therefore, the total time for getting the maximum cavitation erosion can be determined by considering these different stages. On the other hand, the cavitation erosion is strongly dependent upon the flow velocity in the cavitation field and the 


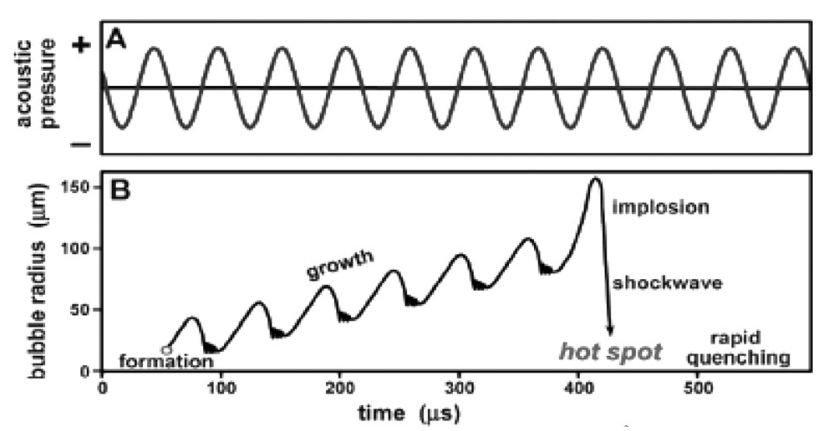

Figure 1: Stages of bubble formation in acoustic cavitation ${ }^{3}$

material damage depends on the duration of the exposure to cavitation. ${ }^{9}$

Thus, the different flow structure occurred below the sonotrode and the exposure time can cause different material damage. A Conical Bubble Structure (CBS) was observed for water and thick round layers were apparent for glycerin at $100 \%$ power. ${ }^{10}$ These bubble structures had different flow characteristics and also had different effects in terms of material damage in the cavitation field. Another important test parameter that effects the cavitation erosion rate was amplitude, a typical CBS was formed below the sonotrode tip in a water tank at a $50 \mu \mathrm{m}$ amplitude, and the increase in amplitude led to a higher number of small cavitation bubbles and selecting a different gap distance between the sonotrode tip and the opposite solid wall can cause a difference in the number of detected micro bubbles. ${ }^{11}$ Thus, the collapsing bubbles density, which can cause material loss, varies by selecting different gap distances. The acoustic power level used in the acoustic cavitation tests also influenced the cavitation erosion rate of the material. As the power amplitude increased from $100 \mathrm{~W}$ to $400 \mathrm{~W}$, the bubbles reached a radius of 4.53 times greater than their initial radius. ${ }^{12}$ For this reason, an increase in the power amplitude can cause higher material damage due to the growing velocity and bubble radius in the acoustic cavitation field. Consequently, the cavitation erosion rate of different materials obtained by using a standard vibratory device depends on the test parameters, such as acoustic power level, amplitude of the sonotrode, liquid type, test duration and the sonotrode type. However, there are a small number of studies related to the gap distance effect on the cavitation erosion in the available literature..$^{13,14}$ In the present study, flat aluminum samples were cavitated by using an indirect method and the reason for this is to determine the minimum gap distance that gives the highest delamination area in a particular zone. This will reduce the total test time and also energy-consumption costs for the industrial processes. Our ultimate goal is to develop a new test methodology in which coating quality and homogeneity of the valve pieces exposed to the cavitation. In the magnet-type injector, the valve piece that separates the high-pressure and the low-pressure regions is one of the most critical parts. This piece is coated with $\mathrm{Cr}-\mathrm{Ni}$ coating material to reduce or minimize the effect of cavitation. Therefore, the results obtained by this work will then be used to develop the coating quality test methodology of valve pieces having angled surfaces.

\section{EXPERIMENTAL PART}

There are two types of application methods for vibration devices: (1) the direct method and (2) the indirect method. ${ }^{6-8}$ As a result of the oscillating of the horn, the bubbles are generated and directed to the surface of the sample to achieve cavitation erosion in a specified test run. The experimental setup and the test parameters used in this study are shown in Figure 2. The samples used in this study were a cylindrical part made of Aluminum 6061-T6 material, having a diameter of $16 \mathrm{~mm}$ and a thickness of $8 \mathrm{~mm}$, with flat surface for the elimination of geometrical effects. Eight different test cases were

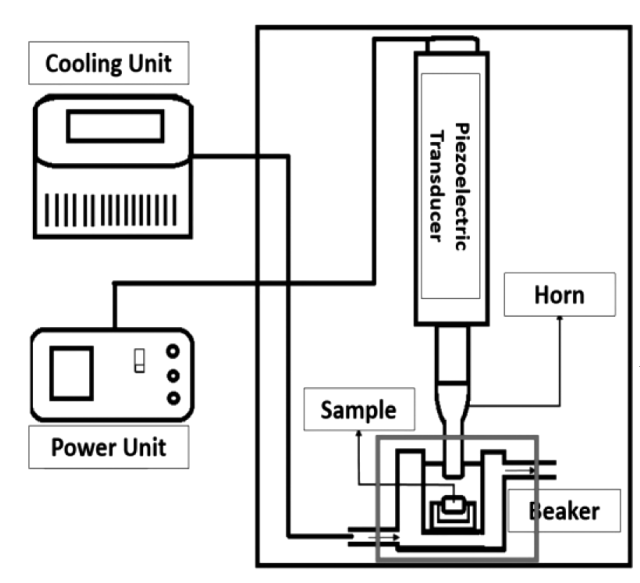

(2a)

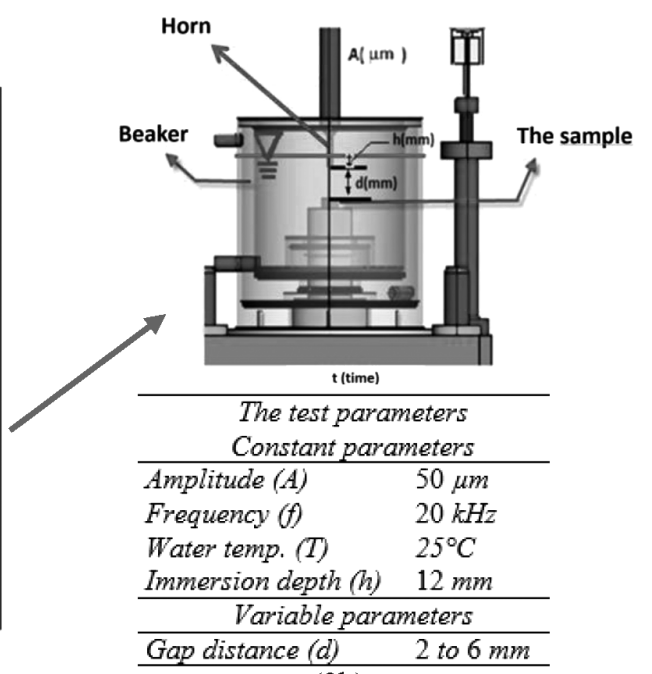

(2b)

Figure 2: a) The experimental setup and b) the test parameters of acoustic cavitation device 
selected to evaluate the effects of the distance between the flat horn and the sample (Figure $2 \mathbf{b}$ ) on the cavitation erosion. The tests were repeated five times for each case to confirm the experimental results under the same conditions. According to our previous experiments, if the gap distance is less than $2 \mathrm{~mm}$ or greater than $6 \mathrm{~mm}$, the cavitation effect is dramatically reduced. Therefore, the gap distance interval was varied from 2 $\mathrm{mm}$ to $6 \mathrm{~mm}$ and two different test durations of $45 \mathrm{~min}$ and $90 \mathrm{~min}$ were applied to examine these effects, whereas the other test parameters remained constant. An optical microscope was used to determine the surface delamination areas where the cavitation erosion occurs and the high-precision scale with $0.01 \mathrm{mg}$ readability was used for measuring the total mass loss due to the cavitation erosion during each test. A high-speed camera with $1357 \mathrm{fps}$ at VGA resolution was used to visualize the shape and the behavior of the flow characteristics. The test device used in this study allows recording energy values with $100 \mathrm{~ms}$ steps via a direct connection with a computer.

\section{RESULTS}

Before starting the cases, a high-speed camera was used to determine the shape and the structure of the bubble cloud that the flat horn created in the distilled water shown in Figures 3a and 3b. As a result of these images, we can easily say that the cone-shaped bubble cloud was observed for all cases. The structure of the bubble cloud derived from the image of the high-speed camera for different gaps is shown in Figure 4. From these results, the structure of cone-shaped bubble cloud was maintained for all cases, but the dimensions of cone shape changed depending on the gap distances. Thus, the affected area on the material was changed by selecting different gap distances, as shown in Figure 5.

The total mass-loss values depending on the cavitation erosion are shown in Table 1. The cumulative mass loss was ranged from $0.8 \mathrm{mg}$ to $1.5 \mathrm{mg}$ for Case- 1 , whereas this value was measured between $2 \mathrm{mg}$ and 2.80 $\mathrm{mg}$ for Case-2. From these results we can say that when the gap distance increased from $2 \mathrm{~mm}$ to $3 \mathrm{~mm}$, the maximum total mass loss was nearly doubled. If the gap distance continued to increase to a value of $3.5 \mathrm{~mm}$ (Case-3), the cumulative mass loss was measured between $4.80 \mathrm{mg}$ and $6.50 \mathrm{mg}$ at the end of the $90 \mathrm{~min}$ testing period. From the comparison of the result of the first three cases, the cumulative mass loss increased nonlinearly with the gap distance. If the gap distance was selected higher than $3.5 \mathrm{~mm}$, then the cumulative mass loss gradually decreased for Cases 4-6. This means that the optimum gap distance considering the maximum total mass loss was achieved for Case-3, which had a gap

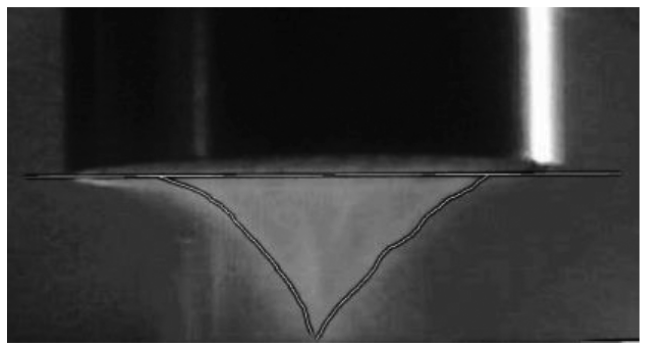

(a)

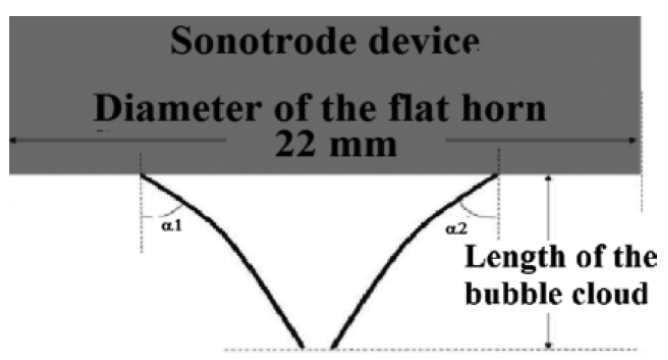

(b)

Figure 3: The shape of the bubble cloud: a) the image taken from a high-speed camera, b) the structure of the bubble cloud derived from image of a high-speed camera

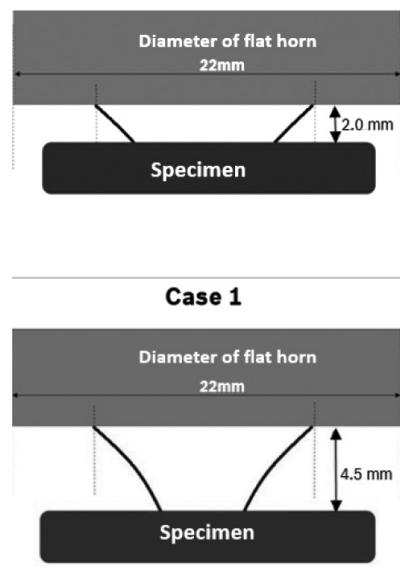

Case 5

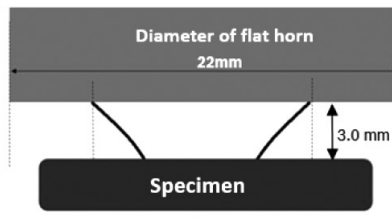

Case 2

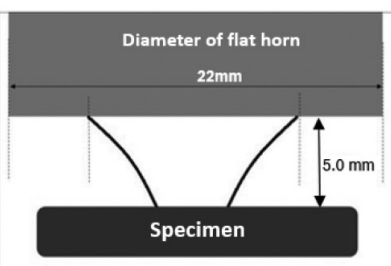

Case 6

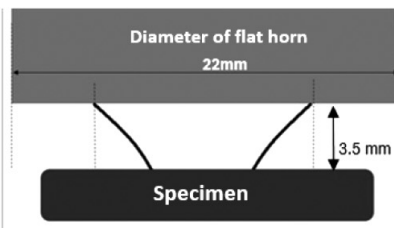

Case 3

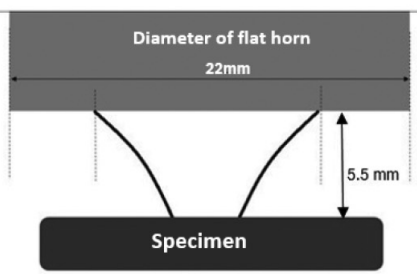

Case 7

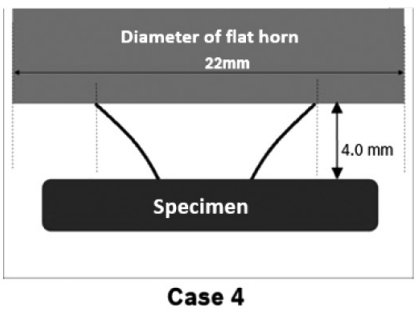

Case 4

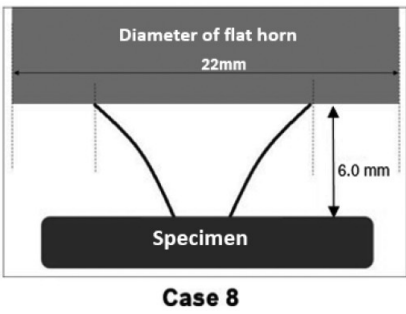

Figure 4: The locations of Al specimens in the bubble cloud with different gaps 
H. DURSUN et al.: EXPERIMENTAL INVESTIGATION OF THE CAVITATION EROSION OF A FLAT ALUMINUM PART ...

Table 1: The measured mass loss values for all cases

\begin{tabular}{|c|c|c|c|c|c|c|c|c|c|c|c|c|}
\hline \multirow{3}{*}{ Sample } & \multicolumn{12}{|c|}{ Total mass loss values obtained from experiments } \\
\hline & \multicolumn{3}{|c|}{ Case-1 $/ d=2.0 \mathrm{~mm}$} & \multicolumn{3}{|c|}{ Case-2 / $d=3.0 \mathrm{~mm}$} & \multicolumn{3}{|c|}{ Case- $3 / d=3.5 \mathrm{~mm}$} & \multicolumn{3}{|c|}{ Case $-4 / d=4.0 \mathrm{~mm}$} \\
\hline & $0-45 \min$ & $45-90 \mathrm{~min}$ & Sum & $0-45 \min$ & 45-90 min & Sum & $0-45 \mathrm{~min}$ & $45-90 \mathrm{~min}$ & Sum & $0-45 \min$ & $45-90 \mathrm{~min}$ & Sum \\
\hline 1 & 0.30 & 0.50 & 0.80 & 0.90 & 1.90 & 2.80 & 1.60 & 3.80 & 5.40 & 1.10 & 3.20 & 4.30 \\
\hline 2 & 0.20 & 0.70 & 0.90 & 0.70 & 1.40 & 2.10 & 2.30 & 4.20 & 6.50 & 1.70 & 2.80 & 4.50 \\
\hline 3 & 0.60 & 0.90 & 1.50 & 0.70 & 1.30 & 2.00 & 2.60 & 3.90 & 6.50 & 0.80 & 2.20 & 3.00 \\
\hline 4 & 0.40 & 0.70 & 1.10 & 0.80 & 1.80 & 2.60 & 1.50 & 3.30 & 4.80 & 1.40 & 2.90 & 4.30 \\
\hline 5 & 0.20 & 0.60 & 0.80 & 0.80 & 1.80 & 2.60 & 2.50 & 2.40 & 4.90 & 1.40 & 2.10 & 3.50 \\
\hline \multirow[t]{3}{*}{ Avg } & 0.34 & 0.68 & 1.02 & 0.78 & 1.64 & 2.42 & 2.10 & 3.52 & 5.62 & 1.28 & 2.64 & 3.92 \\
\hline & \multicolumn{3}{|c|}{ Case $-5 / d=4.5 \mathrm{~mm}$} & \multicolumn{3}{|c|}{ Case $-6 / d=5.0 \mathrm{~mm}$} & \multicolumn{3}{|c|}{ Case- $7 / d=5.5 \mathrm{~mm}$} & \multicolumn{3}{|c|}{ Case $-8 / d=6.0 \mathrm{~mm}$} \\
\hline & $0-45 \min$ & 45-90 min & Sum & $0-45 \mathrm{~min}$ & $45-90 \mathrm{~min}$ & Sum & $0-45 \mathrm{~min}$ & $45-90 \min$ & Sum & $0-45 \min$ & $45-90 \min$ & Sum \\
\hline 1 & 1.30 & 1.60 & 2.90 & 0.90 & 1.90 & 2.80 & 0.40 & 1.10 & 1.50 & 0.20 & 0.80 & 1.00 \\
\hline 2 & 0.90 & 1.30 & 2.20 & 1.30 & 0.80 & 2.10 & 0.20 & 0.80 & 1.00 & 0.20 & 0.50 & 0.70 \\
\hline 3 & 0.30 & 2.20 & 2.50 & 0.40 & 2.10 & 2.50 & 0.50 & 0.80 & 1.30 & 0.40 & 0.80 & 1.20 \\
\hline 4 & 0.70 & 2.00 & 2.70 & 0.60 & 1.70 & 2.30 & 0.50 & 0.70 & 1.20 & 0.20 & 1.00 & 1.20 \\
\hline 5 & 1.10 & 1.90 & 3.00 & 0.20 & 2.90 & 3.10 & 0.40 & 1.40 & 1.80 & 0.10 & 1.30 & 1.40 \\
\hline Avg & 0.86 & 1.80 & 2.66 & 0.68 & 1.88 & 2.56 & 0.40 & 0.96 & 1.36 & 0.22 & 0.88 & 1.10 \\
\hline
\end{tabular}

distance selected of $3.5 \mathrm{~mm}$. We can easily say that the gap distance had a great effect on the cavitation erosion of an aluminum sample.

Another result is that the test duration affects could not be neglected and the total mass loss, which gradually increased over time, and the maximum total mass loss were measured for Case- 3 in all experiments. This means that there was no need for more testing time if the maxi-
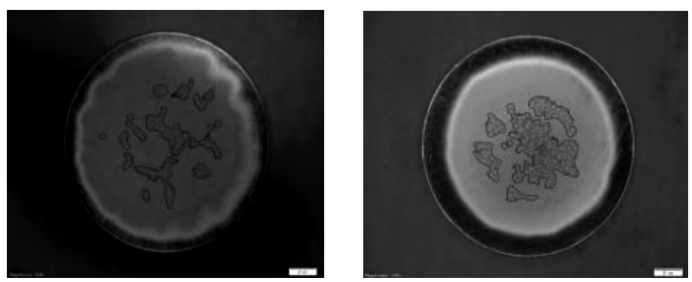

a. Case-1 $(\mathrm{d}=2.0 \mathrm{~mm})$
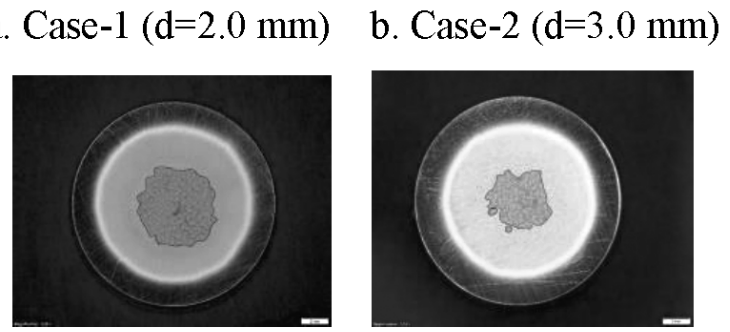

c. Case-3 $(d=3.5 \mathrm{~mm})$
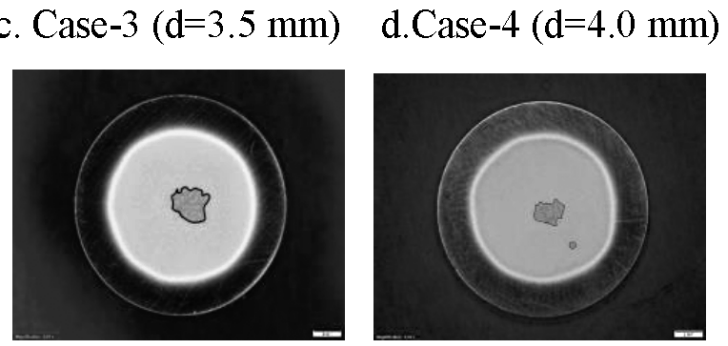

e. Case-6 $(d=5.0 \mathrm{~mm}) \quad$ f.Case $-8(d=6.0 \mathrm{~mm})$

(1) mum cavitation erosion is required and less power is spent. According to the optical microscope photographs at $90 \mathrm{~min}$, the surface area affected by cavitation erosion was nearly the same for the first two cases and the heterogeneous delamination area was observed for these cases (Figure 5.1a). The mass losses are also low. However, the delaminated surface area can be assumed to be homogeneous for Case- 3 compared to Case- 1 and
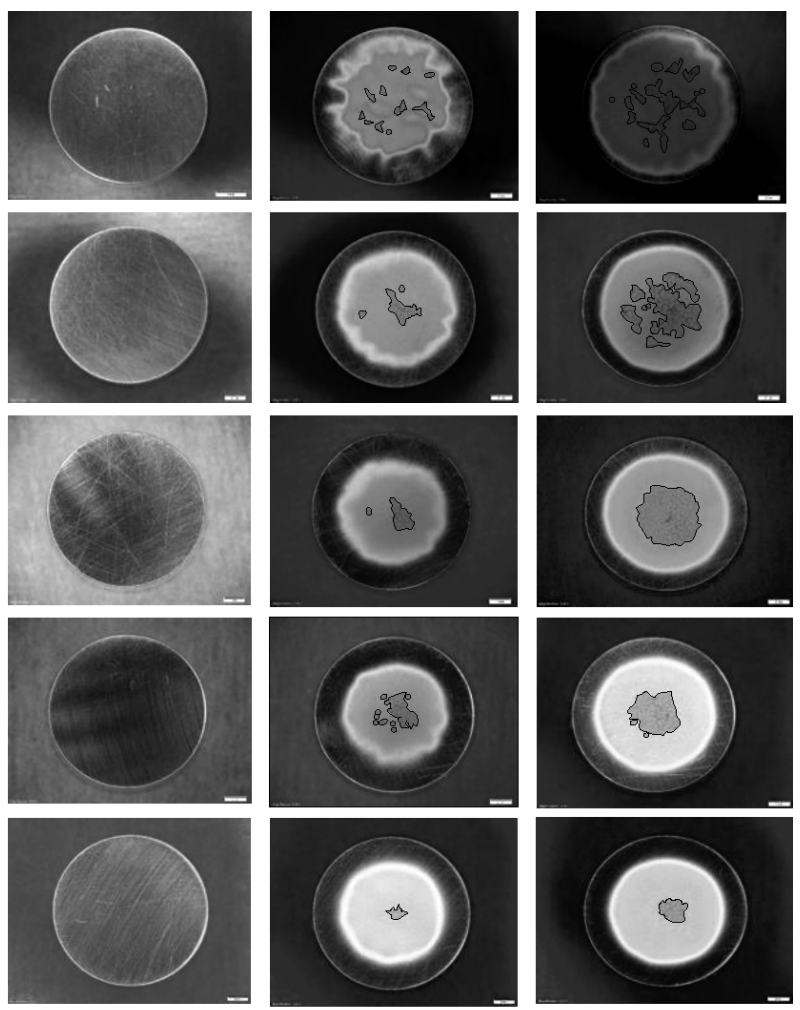

a. 0 min

b. $45 \mathrm{~min}$

(2) c. $90 \mathrm{~min}$

Figure 5: Optical microscope photographs of the Al sample: (1) the distribution of delaminated area of the Al sample for Case 1-4, and Case-8 at 90 min of testing period, (2) optical microscope photographs of the Al samples for the same cases (a-e) 


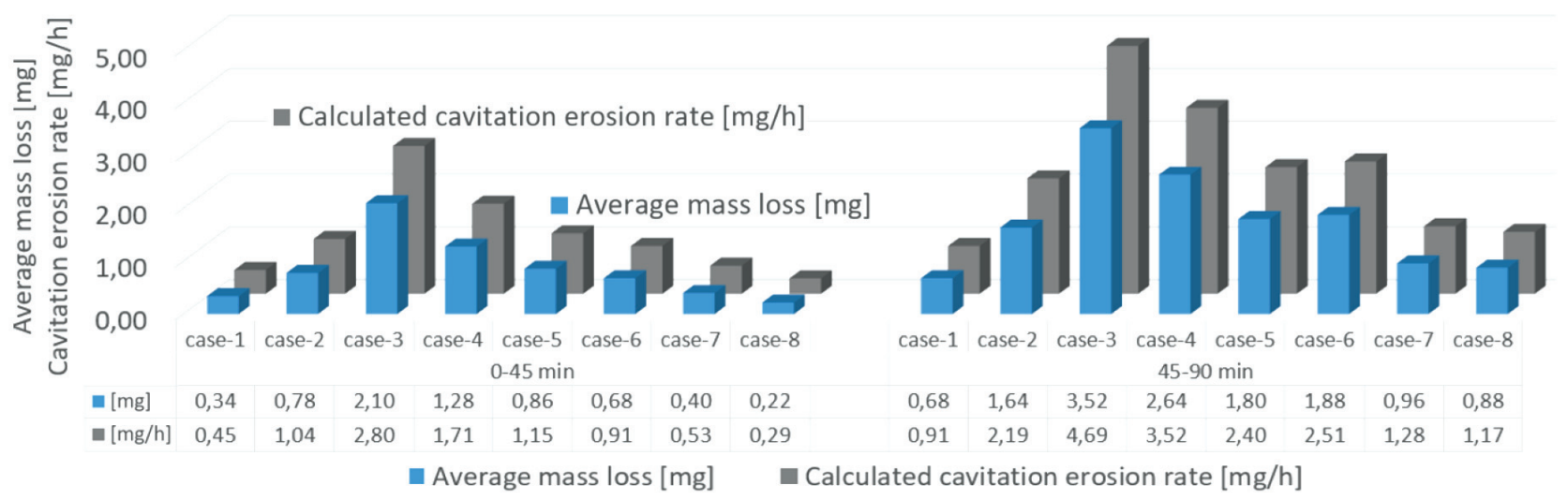

Figure 6: The average mass-loss measurements and calculated average cavitation erosion rate (mg/h) for each case

Case-2 (Figure 5.1b). According to the optical microscope photographs in Figure 5, a certain gap distance range is required to obtain a homogeneous distribution of the delamination area. In addition, the mass losses are also high. As the distance between the aluminum sample and the sonotrode increases, the effects of cavitation decrease, but the delaminated area concentrated at a more central point (Figures 5.1c and 5.1d). It can be said that the reason for this is the reduction of the affected area of the cone-shaped bubble structure on the material. The average mass loss and the calculated average cavitation erosion rate obtained from all the experiments for the two different test periods are shown in Figure 6. From these results, the cavitation erosion rates were calculated to be between $1.5 \mathrm{mg} / \mathrm{h}$ and $2 \mathrm{mg} / \mathrm{h}$ for case-2, case- 5 and case- 6 . This value was changed to be between $0.8 \mathrm{mg} / \mathrm{h}$ and $1.2 \mathrm{mg} / \mathrm{h}$ for case- 7 and case- 8 . On the other hand, the lowest and the highest values were obtained for case- 1 and case- 3 , respectively. From these results, we can easily say that the calculated cavitation erosion rates of case- 2 , case- 5 and case- 6 were close to each other. The cavitation erosion rates of case- 7 and case- 8 were similar.

The electric power of the horn for each case was shown in Figure 7. From these results, the lowest energy consumption was obtained for Case-7 and case-8, but these cases had smaller delaminated areas and lower cumulative mass loss. From the comparison of the energy-consumption data for all cases, the homogenous delaminated area that provides the minimum energy

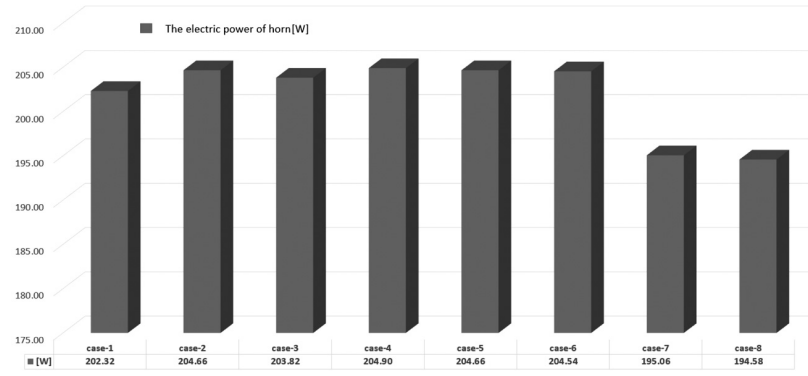

Figure 7: The electric power (W) of horn for all cases consumption per unit mass loss was obtained for case-3 and the electric power was obtained about 203.82 W for case-3.

\section{DISCUSSION}

The cumulative mass loss was changed nonlinearly with different gap distances used in this experimental study. There was a range of distances that the flat horn works most effectively. The area affected by the cavitation erosion decreased with the increasing gap distance due to the geometry of the V-shape bubble cloud. However, where the gap distance was reduced too much, the power of the cavitation decreases, even if the affected area increased. The difficulty of the indirect method used in this study was the complication of controlling the flow characteristics between the flat horn and the sample. It was confirmed that the flat horn generated a V-shaped cavitation field (bubble cloud) during the oscillations at high frequency in the water.

\section{CONCLUSIONS}

From the result of this experimental study, we can easily say that the gap distance is an important parameter that must be determined when considering the energy consumption, test time and maximum homogeneous delaminated area in a specific cavitation test. When the gap distance was less than $3.5 \mathrm{~mm}$, it was observed that the distribution of the delaminated area was heterogeneous. It was determined that the $3.5-\mathrm{mm}$ distance is the optimum gap for the 22-mm-diameter flat horn and the maximum total mass loss was measured for Case- 3 in all experiments. The homogenous delaminated area that provides the minimum energy consumption per unit mass loss was obtained for case- 3 and the electric power was obtained at about $203.82 \mathrm{~W}$ for case- 3 . The test duration effects could not be neglected and this means that there was no need for more testing time if the maximum cavitation erosion was required and also less power. In further studies we aim to develop the CFD (Computational Fluid Dynamics) model for obtaining the 
effects of other test parameters of this experiment, which will be helpful to understand the control mechanisms of the cone-like bubble structure below the sonotrode tip.

\section{Acknowledgment}

The authors would like to acknowledge the company Bosch for supporting this research by providing the experimental test unit.

\section{REFERENCES}

${ }^{1}$ P. Eisenberg, Cavitation, http://web.mit.edu/hml/ncfmf/16CAV.pdf (1969), 10.06.2018

${ }^{2}$ A. Kjølle, Hydropower in Norway, Mechanical equipment, Survey, Norwegian University of Science and Technology, Trondheim 2001

${ }^{3}$ S. V. Sancheti, P. R. Gogate, A review of engineering aspects of intensification of chemical synthesis using ultrasound, Ultrasonics Sonochemistry 36 (2017) 527-543, doi:10.1016/j.ultsonch.2016. 08.009

${ }^{4}$ ASTM G32-10:2010 Standard test method for cavitation erosion using vibratory apparatus, ASTM International, West Conshohocken

${ }^{5}$ V. Cojocaru, V. C. Campian, D. Frunzaverde, A comparative analysis of the methods used for testing the cavitation erosion resistance on the vibratory devices, U. P. B. Sci. Bull., Series D: Mechanical Engineering, 77 (2015), 257-262

${ }^{6}$ M. D. Nedeloni, V. Cojocaru, R. Ciubotariu, D. Nedelcu, Cavitation erosion tests performed by indirect vibratory method on stainless steel welded samples with hardened surface, Anallele Universitat II "Eftimie Murgu” Resita Anul XIX, 2012
${ }^{7}$ C. I. Lupinca, M. D. Nedeloni, Comparative study regarding the cavitation erosion behavior of $\mathrm{Cu}$ and $\mathrm{Al}$ alloys, International Journal of Latest Research in Science and Technology, 3 (2014), 95-99

${ }^{8}$ M. D. Nedeloni, N. Potoceanu, D. Florea, D. Chirus, Research through the stationary specimen method of the X20Cr13 stainless steel used for hydraulic pumps, Materials Science Forum, 782 (2014), 251-256, doi:10.4028/www.scientific.net/msf.782.251

${ }^{9}$ K. H. Kim, G. Chahine, J. P. Franc, A. Karimi, Advanced experimental and numerical techniques for cavitation erosion prediction, Fluid Mechanics and its Applications, Springer, Berlin 2014

${ }^{10}$ I. Tzanakis, G. S. B. Lebon, D. G. Eskin K. A. Pericleous, Characterizing the cavitation development and acoustic spectrum in various liquids, Ultrasonics Sonochemistry, 34 (2017), 651-662, doi:10.1016/j.ultsonch.2016.06.034

${ }^{11}$ S. Müller, M. Fischper, S. Mottyll, R. Skoda, J. Hussong, Analysis of the cavitating flow induced by an ultrasonic horn - Experimental investigation on the influence of actuation phase, amplitude and geometrical boundary conditions, EPJ Web of Conferences, 67 (2014), 02079, doi:10.1051/epjconf/20146702079

${ }^{12}$ B. Sajjadi, A. A. A. Raman, S. Ibrahim: Influence of ultrasound power on acoustic streaming and micro-bubbles formations in a low frequency sono-reactor: Mathematical and 3D computational simulation, Ultrasonics Sonochemistry, 24 (2015), 193-203, doi:10.1016/j.ultsonch.2014.11.013.

${ }^{13}$ F. Bai, K-A. Saalbach, J. Twiefel, J.Wallaschek, Effect of different standoff distance and driving current on transducer during ultrasonic cavitation peening, Sensors and Actuator A: Physical, 261 (2017), 274-279, doi:10.1016/j.sna.2017.05.002

${ }^{14}$ I. Ibanez, M. Hodnett, B. Zeqiri, M. N. Frota, Correlating inertial acoustic cavitation emissions with material erosion resistance, Physics Procedia, 87 (2016), 16-23, doi:10.1016/j.phpro.2016. 12.004 